\title{
Pengaruh Tenaga Kerja (Human Capital) dan Daya Dorong Investasi terhadap Pertumbuhan Ekonomi Provinsi Papua (Studi Kasus)
}

\author{
Abdul Rasyid \\ Fakultas Ekonomi dan Bisnis Universitas Yapis Papua \\ adamsalrasyid@yahoo.com \\ Rahmatia \\ Fakultas Ekonomi dan Bisnis Universitas Hasanuddin \\ Ahmad Jusmin \\ Entar Sutisman \\ La Ode Marihi \\ Suratini \\ Fakultas Ekonomi dan Bisnis Universitas Yapis Papua \\ (Diterima: 03-Januari-2020; dipublikasikan: 31-Januari-2020)
}

\begin{abstract}
The economic development efforts of the Papua province should focus on increasing employment opportunities and increasing investment as a stimulus to economic growth, thereby distributing community opportunities in every productivity Can be acquired for community welfare and economic development. Therefore, each autonomous region has the freedom to develop all potential and assets owned, especially the potential of natural resources that can be used as the main asset in the development of the regional economy in general. Therefore, it is necessary to analyze how the influence of Labour (Human Capital) and the power of investment towards economic growth in the Papua province (case study). The results showed that: the provision of employment opportunities in the Papua province is influenced by investment and real investment affects the provision of employment opportunities. This is because there is a lot of investment supported by the Government through a development financing budget that use more oriented to the development of sectors that are less absorbing workforce. Investment and Labour, both have no positive effect on the percapita income and economic growth.
\end{abstract}

Keywords: Labor; Investment (PMA and PMDN); Economic growth

\begin{abstract}
Abstrak
Upaya pembangunan ekonomi daerah Provinsi Papua perlu menitikberatkan pada peningkatan kesempatan kerja dan peningkatan investasi sebagai rangsangan terhadap pertumbuhan ekonomi, sehingga distribusi kesempatan masyarakat dalam setiap produktivitas sektoral dapat diperoleh untuk kesejahteraan masyarakat dan pembangunan ekonomi. Karena itu setiap daerah otonom memiliki keleluasan untuk mengembangkan segala potensi dan aset-aset yang dimiliki, khususnya potensi sumber daya alam daerah yang dapat dijadikan sebagai asset andalan dalam pengembangan ekonomi daerah secara umum. Oleh sebab itu perlu di analisis bagaimana Pengaruh Tenaga Kerja (Human Capital) Dan Daya Dorong Investasi Terhadap Pertumbuhan Ekonomi di Provinsi Papua (Studi Kasus). Hasil penelitian menunjukkan bahwa : Penyediaan kesempatan kerja di propinsi Papua dipengaruhi oleh Investasi dan Investasi nyata berpengaruh terhadap penyediaan kesempatan kerja. Hal ini disebabkan karena investasi yang ada banyak di dukung oleh pemerintah melalui anggaran pembiayaan pembangunan yang penggunaanya lebih berorientasi kepada pembangunan sektor -sektor yang kurang menyerap tenaga kerja. Investasi dan tenaga kerja, sama-sama tidak berpengaruh positif terhadap pendapatan perkapita dan pertumbuhan ekonomi.
\end{abstract}

Kata Kunci: Tenaga Kerja; Investasi (PMA dan PMDN) Pertumbuhan Ekonomi 


\section{PENDAHULUAN}

Jauh sebelum era orde baru, strategi pembangunan di Indonesia secara teori telah diarahkan pada usaha pencapaian laju pertumbuhan ekonomi yang tinggi. Hal ini sesuai dengan harapan dan cita-cita luhur para pendiri bangsa yang tersirat dalam Pembukaan Undang-Undang Dasar Negara Republik Indonesia Tahun1945 yaitu bagaimana bangsa Indonesia dapat mewujudkan masyarakat yang adil dan makmur. Namun kenyataan yang ada tidak seperti dibayangkan, bahkan ada kecendrungan lebih menitikberatkan pada tujuan-tujuan politik dan kurang memperhatikan pembangunan ekonomi. Sehingga perkembangan ekonomi yang tadinya menjadi perioritas utama menjadi terabaikan, bahkan dipenghujung tahun 2018, nilai tukar rupiah terhadap dolar Amerika Serikat sudah mencapai level $\mathrm{Rp}$ 15.000,00 per dolar AS.

Oleh karena itu, upaya pembangunan ekonomi daerah sebagai penyangga ekonomi nasional perlu menitikberatkan pada peningkatan kesempatan kerja dan peningkatan investasi sebagai rangsangan terhadap pertumbuhan ekonomi. Hal ini dilakukan agar distribusi kesempatan masyarakat dalam setiap produktivitas sektoral dapat diperoleh sehingga kesejahteraan masyarakat lebih meningkat dan pembangunan ekonomi dapat terus tumbuh. Dalam upaya mencapai tujuan tesebut, maka pemerintah daerah dan masyarakat berusaha bersama-sama terlibat aktif dengan menggunakan segala potensi yang ada untuk membangun perekonomian daerah. Perubahan secara umum yang terjadi pada suatu wilayah perekonomian dapat dilihat dari tingkat inflasi, pengangguran, kesempatan kerja, hasil produksi, dan sebagainya. Selain itu perkembangan ekonomi suatu daerah juga dapat ditinjau dari perubahan-perubahan stabilitas keseimbangan kapasitas perekonomiannya dalam jangka waktu yang lama.

Menurut Djoyohadikusumo (1994), suatu perekonomian dikatakan mengalami pertumbuhan atau perkembangan jika tingkat kegiatan ekonominya meningkat atau lebih tinggi jika dibandingkan dengan tahun sebelumnya. Berbeda dengan pembangunan ekonomi yang mengandung arti lebih luas dan mencakup perubahan pada tata susunan ekonomi masyarakat secara menyeluruh. Meskipun istilah pertumbuhan ekonomi dan pembangunan ekonomi dianggap sama, namun biasanya istilah pembangunan ekonomi (economic development) lebih dikenal di negara sedang berkembang, sedangkan istilah pertumbuhan ekonomi (economic growth) lebih dikenal di negara maju. Oleh karena itu, pertumbuhan ekonomi adalah suatu proses perubahan yang terus menerus dan usaha suatu negara untuk memperbesar atau meningkatkan pendapatan masyarakatnya.

Sejalan dengan dikeluarkannya Undangundang Nomor 21 Tahun 2001 tentang otonomi khusus bagi Provinsi Papua, maka pemerintah daerah Provinsi Papua diberikan pelimpahan kewenangan untuk mengurus dan mengatur rumah tangga daerahnya sendiri. Oleh karena itu, setiap daerah otonom memiliki keleluasan untuk mengembangkan segala potensi dan asetaset yang dimiliki, khususnya potensi sumber daya alam daerah yang dapat dijadikan sebagai aset andalan dalam pengembangan ekonomi daerah secara umum. Sebagai konsekwensi dari upaya pengembangan aset sumber daya alam di daerah, maka sangat diperlukan adanya anggaran dalam upaya mendukung pelaksanaan pengelolaan sumber daya alam, dengan harapan pengembangannya dapat berjalan sesuai dengan rencana pemanfaatan dan pengelolaan yang lebih optimal.

Pertumbuhan ekonomi suatu wilayah dapat mencerminkan keberhasilan pembangunan ekonomi pada wilayah tersebut. Apabila suatu wilayah dapat meningkatkan laju pertumbuhan ekonominya maka wilayah tersebut sudah mampu melaksanankan pembangunan ekonomi dengan baik. Akan tetapi yang masih menjadi masalah dalam pembangunan ekonomi ini adalah apakah pertumbuhan 
ekonomi yang terjadi pada suatu wilayah sudah merata di seluruh lapisan masyarakat. Karena harapan pertumbuhan ekonomi yang tinggi akan dapat meningkatkan pendapatan per kapita masyarakat. Dalam upaya mendorong pembangunan ekonomi tersebut, salah satu usaha yang perlu dilakukan oleh pemerintah khusunya pemerintah daerah Provinsi Papua adalah meningkatkan kualitas sumberdaya manusianya sebagai human capital karena sangat memegang peranan penting didalam mengelolah segala potensi dan sumberdaya daerah.

\section{METODE PENELITIAN}

Metode penelitian yang digunakan dalam penelitian ini adalah metode kuantitatif, yaitu survei dengan pendekatan penelitian kuantititatif. Sedangkan jenis penelitian survei ini memfokuskan pengungkapan pada hubungan kausal antar variabel secara langsung, yaitu penelitian yang diarahkan untuk menyelidiki hubungan sebab berdasarkan pengamatan terhadap akibat yang terjadi. Uji hipotesis dalam penelitian ini digunakan untuk menerangkan hubungan kausal antara variabel dari masing-masing variabel terpilih untuk memastikan bahwa secara kuantitatif hubungan tersebut ada secara langsung antar variabl independen terhadap variabel dependen

Definisi operasional variabel dalam penelitian ini adalah sebagai berikut:

1. Tenaga Kerja (X1) adalah jumlah angkatan kerja yang sudah terserap dalam lapangan kerja.

2. Investasi (X2) adalah besarnya jumlah dana investasi PMDN dan PMA yang diukur dengan milyar rupiah.

3. Pertumbuhan ekonomi (Y) adalah besarnya tingkat pertumbuhan ekonomi dalam setiap tahun yang di ukur dengan persen.

Teknik pengumpulan data menggunakandata panel(Tahun 2007- Tahun 2014). Model analisa yang dipakai untuk mengetahui pengaruh variabel Tenaga Kerja (Human Capital) Dan Daya Dorong Investasi Terhadap Pertumbuhan Ekonomi Provinsi Papua adalah dengan menggunakan metode analisis jalur (Path Analysis Method).

Untuk menghasilkan model persamaan struktural maka-model persamaan struktural tersebut secarasederhana diekspresikan sebagai berikut:

$$
\mathrm{Y}=\mathrm{a}+\mathrm{b} 1 \mathrm{X} 1+\mathrm{b} 2 \mathrm{X} 2+\mathrm{e}
$$

Dimana:

$\begin{array}{lll}\mathrm{Y} & = & \text { Pertumbuhan Ekonomi } \\ \mathrm{X} 1 & = & \text { Tenaga Kerja (Human Capital) } \\ \mathrm{X} 2 & = & \text { Daya Dorong Investasi } \\ \mathrm{b} & = & \text { Koefisien arah regresi } \\ \mathrm{a} & = & \text { Konstanta } \mathrm{Y} \\ \mathrm{e} & = & \text { error terms }\end{array}$

Penelitian ini menggunakan metode penelitian survei dengan pendekatan penelitian kuantititatif. Sedangkan jenis penelitian survei ini memfokuskan pengungkapan pada hubungan kausal antar variabel secara langsung, yaitu penelitian yang diarahkan untuk menyelidiki hubungan sebab berdasarkan pengamatan terhadap akibat yang terjadi. Uji hipotesis dalam penelitian ini digunakan untuk menerangkan hubungan kausal antara variabel dari masing-masing variabel terpilih untuk memastikan bahwa secara kuantitatif hubungan tersebut ada secara langsung antar variabl independen terhadap variabel dependen.

Model analisa yang dipakai untuk mengetahui pengaruh variabel Tenaga Kerja (Human Capital) Dan Daya Dorong Investasi Terhadap Pertumbuhan Ekonomi Provinsi Papua adalah dengan menggunakan metode analisis jalur (Path Analysis Method).

Untuk menghasilkan model persamaan struktural maka-model persamaan struktural tersebut secarasederhana diekspresikan sebagai berikut:

$$
\mathrm{Y} 1=\mathrm{f}(\mathrm{X} 1, \mathrm{X} 2)
$$

Dimana:

Y1 = Pertumbuhan Ekonomi

$\mathrm{X} 1$ = Tenaga Kerja (Human Capital)

$\mathrm{X} 2=$ Daya Dorong Ivestasi 


\section{HASIL DAN PEMBAHASAN}

Salah satu sumberdaya yang dimiliki oleh daerah adalah modal manusia (human capital). Sumber daya manusia yang ada dapat ditingkatkan kualitasnya melalui pendidikan formal dan non formal, sehingga dapat lebih produktif. Masalah yang sering muncul adalah tingginya laju pertumbuhan penduduk yang tidak merata dalam suatu wilayah yang menyebabkan terhambatnya distribusi pembangunan. Oleh karena itu, tidak meratanya jumlah penduduk akan menyebabkan sumber potensial dalam suatu sektor pendapatan negara juga tidak bekerja maksimal. Dampak negatif lainnya adalah terjadinya pengangguran akibat ketidakseimbangan antara jumlah tenaga kerja dengan jumlah kesempatan kerja. Struktur penduduk Provinsi Papua ditunjukkan pada tabel 1 .

Tabel 1 Jumlah dan Persentase Penduduk Provinsi Papua Berdasarkan Jenis kelamin Tahun 2007-2014

\begin{tabular}{lrrrrrr}
\hline Tahun & $\begin{array}{r}\text { Jenis Kelamin (orang) } \\
\text { Laki laki }\end{array}$ & $\begin{array}{c}\text { Proporsi (\%) } \\
\text { Perempuan }\end{array}$ & $\begin{array}{c}\text { Total (orang) } \\
\text { Laki laki }\end{array}$ & Perempuan & & \\
\hline 2007 & 957.522 & 1.067 .671 & 47,28 & 52,72 & 2.025 .193 & 108,16 \\
2008 & 982.023 & 1.096 .308 & 47,25 & 52,75 & 2.078 .331 & 107,77 \\
2009 & 1.007 .146 & 1.125 .716 & 47,23 & 52,67 & 2.132 .862 & 107,61 \\
2010 & 1.032 .916 & 1.155 .915 & 47,19 & 52,81 & 2.188 .831 & 113,40 \\
2011 & 1.544 .785 & 1.383 .965 & 52,75 & 47,25 & 2.928 .750 & 111,62 \\
2012 & 1.664 .076 & 1.480 .505 & 52,92 & 47,08 & 3.144 .581 & 112,40 \\
2013 & 1.603 .158 & 1.429 .330 & 52,87 & 47,13 & 3.032 .488 & 112,16 \\
2014 & 1.631 .306 & 1.459 .741 & 52,76 & 47,24 & 3.091 .047 & 102,83 \\
\hline
\end{tabular}

Sumber Data : BPS Provinsi Papua, Papua Dalam Angka

Berdasarkan tabel 1 dapat dijelaskan bahwa perkembangan jumlah penduduk Provinsi Papua hingga tahun 2014 berjumlah 3.091.047 jiwa dengan komposisi jumlah penduduk laki-laki sebanyak 1.631 .306 jiwa dan perempuan 1.459 .741 jiwa. Perbandingan persentase jumlah penduduk laki-laki dan perempuan adalah $52,76 \%$ penduduk laki-laki berbanding 47,24\% untuk perempuan. Persentase ini menandakan bahwa penduduk laki-laki jauh lebih banyak bila dibandingkan dengan penduduk perempuan. Sejalan dengan itu, maka keterlibatan penduduk laki-laki dalam dunia kerja tentu lebih banyak dibanding perempuan.

Selanjutnya, persoalan yang ada, apakah penduduk yang tergolong dalam usia kerja atau angkatan kerja terserap oleh lapangan kerja yang ada ? jika jawabannya tidak, maka itu menjadi persoalan serius. Hal ini sebagaimana ditunjukkan pada tabel 2 . 
Tabel 2 Jumlah Angkatan Kerja, Bekerja, Pencari Kerja, Tenaga Kerja, Serapan Tenaga Kerja dan Persentase Kesempatan Kerja Di Provinsi Papua Tahun 2007 - 2014

\begin{tabular}{ccccrrc}
\hline Tahun & $\begin{array}{c}\text { Angkatan } \\
\text { Kerja } \\
\text { (orang) }\end{array}$ & $\begin{array}{c}\text { Bekerja } \\
\text { (orang) }\end{array}$ & $\begin{array}{c}\text { Pencari } \\
\text { Kerja } \\
\text { (orang) }\end{array}$ & $\begin{array}{c}\text { Jumlah Tenaga } \\
\text { Kerja (orang) }\end{array}$ & $\begin{array}{c}\text { Serapan } \\
\text { Tenaga Kerja } \\
\text { (orang) }\end{array}$ & $\begin{array}{c}\text { Kesempatam } \\
\text { Kerja (\%) }\end{array}$ \\
\hline 2007 & 990.774 & 941,100 & 48.674 & 1.294 .494 & 2.586 & 0,26 \\
2008 & 1.075 .214 & 1.028 .023 & 47.191 & 1.401848 & 4.165 & 0,39 \\
2009 & 1.128 .036 & 1.082 .028 & 46.008 & 1.450 .851 & 22.939 & 2,03 \\
2010 & 1.510 .176 & 1.456 .545 & 111.077 & 1.864 .589 & 5.373 & 0,36 \\
2011 & 1.536 .728 & 1.476 .227 & 60.501 & 1.958 .892 & 11.755 & 0,76 \\
2012 & 1.585 .434 & 1.527 .933 & 57.501 & 2.009 .145 & 17.488 & 1,10 \\
2013 & 1.688 .876 & 1.634 .332 & 54.544 & 2.165 .070 & 4.398 & 0,26 \\
2014 & 1.675 .113 & 1.617 .437 & 57676 & 2.129 .404 & $4.398^{*}$ & $0,26 *$ \\
\hline
\end{tabular}

Sumber Data: BPS Provinsi Papua, Papua Dalam Angka, di olah Tahun 2018

*) Data tidak tersaji dan digunakan data sebelumnya

Berdasarkan tabel 2 tersebut di atas, dapat diketahui bahwa angkatan kerja di Provinsi Papua setiap tahunnya terus bertambah, sedangkan serapan tenaga kerja relatif menurun dan stabil. Pada sisi lain selisih serapan tenaga kerja dari tahun ke tahun juga cukup tinggi. Selain itu persentase kesempatan kerja dari angkatan kerja yang ada rata- rata di bawah satu persen, kecuali tahun 2009 dan tahun 2012 yang persentase tingkat kesempatan kerja rata-rata di atas satu persen yaitu masingmasing 2,03 persen dan 1,10 persen.

Lewis dalam teorinya mengenai ketenagakerjaan mengemukakan bahwa kelebihan pekerja merupakan kesempatan dan bukan masalah. Kelebihan pekerja satu sektor akan memberikan andil terhadap pertumbuhan output dan penyediaan pekerja di sektor lain. Selanjutnya Lewis mengemukakan bahwa ada dua sektor di dalam perekonomian negara sedang berkembang, yaitu sektor modern dan sektor tradisional.

Menganalisis pernyataan dari teori yang dikemukakan oleh Lewis tersebut tentu menimbulkan pertanyaan baru, apakah kelebihan tenaga kerja yang ada tersebut dapat diserap oleh sektor lain? sebab tidak semua penduduk yang tergolong dalam usia kerja mempunyai keterampilan, sehingga ada kemungkinan akan menjadi pengangguran.

\section{Daya Dorong Investasi}

Permasalahan mendasar yang dihadapi oleh pemerintah daerah mengejar pertumbuhan ekonomi sangat kompleks, di antaranya adalah kesempatan kerja dan pendapatan per kapita. Seperti halnya di tingkat nasional, maka masalah ketenagakerjaan dan pendapatan per kapita masyarakat di Propinsi Papua juga merupakan salah satu masalah pokok yang perlu mendapat perhatian dalam perencanaan pembangunan daerah, sehingga kehadiran investasi sangatlah berarti. Selain kehadirannya mendorong pertumbuhan ekonomi, juga sebagai penyokong dan penyedia lapangan kerja. 
Tabel 3 Jumlah Investor, PMA, PMDN dan Persentase PMA dan PMDN Provinsi Papua Tahun 2007 - 2017

\begin{tabular}{cccccc}
\hline Tahun & Total Investor & Jumlah PMA & Persentase PMA & Jumlah PMDN & Persentase PMDN \\
\hline 2007 & 86 & 54 & 62,79 & 32 & 37,21 \\
2008 & 93 & 65 & 69,89 & 28 & 30,11 \\
2009 & 103 & 74 & 71,85 & 29 & 28,15 \\
2010 & 108 & 79 & 73,15 & 29 & 26,85 \\
2011 & 117 & 87 & 74,36 & 30 & 25,64 \\
2012 & 137 & 95 & 69,34 & 42 & 30,66 \\
2013 & 168 & 103 & 61,31 & 65 & 38,69 \\
2014 & 186 & 108 & 58,06 & 78 & 41,94 \\
\hline
\end{tabular}

Sumber Data : Badan Perijinan Dan Penanaman Modal Provinsi Papua, di Olah Tahun 2018

Berdasarkan tabel 3 dapat dijelaskan bahwa besarnya laju perkembangan investasi di Provinsi Papua sangat dipengaruhi oleh peranan kebijakan dari pemerintah daerah. Hingga Tahun 2014 persentase pertumbuhan Penanaman Modal Asing (PMA) mencapai 58,06 persen dengan jumlah investor sebanyak 108 investor, sedangkan persentase laju pertumbuhan investasi Penanaman Modal Dalam Negeri (PMDN) untuk Tahun 2014 sebesar 41,04 persen dengan jumlah investor sebanyak 78 investor dari total jumlah investor sebanyak 186 investor.

Peranan kedua Investasi ini sangat berpengaruh terhadap perkembangan dan pertumbuhan ekonomi khususnya dalam serapan tenaga kerja dan peningkatan kesejahteraan masyarakat lokal. Perkembangan PMA dan PMDN terus mengalami pertumbuhan, hal ini menandakan bahwa Papua akan menjadi wilayah yang potensial untuk berinvestasi. Namun demikian kendala masih saja ada, khususnya terkait dengan hak kepemilikan dan pembebasan lahan. Selain itu birokrasi sistem perizinan cukup panjang dan rendahnya dukungan sarana dan prasarana untuk kegiatan investasi.

Sehubungan dengan itu, maka pemerintah daerah harus melakukan berbagai upaya agar para investor, baik investor lokal maupun investor asing mau melakukan investasi di Provinsi Papua, sehingga di kemudian hari dapat memberikan peningkatan pendapatan bagi pemerintah daerah dan kesejahteraan masyarakat Provinsi Papua secara umum.

\section{Pertumbuhan Ekonomi}

Terjadinya perbedaan tingkat pertumbuhan ekonomi antar wilayah disebabkan oleh adanya pengaruh internal dan eksternal. Faktor-faktor internal yang dimaksud meliputi potensi ekonomi dan sumberdaya yang dimiliki oleh masing masing wilayah. Karena itu pertumbuhan yang tinggi belum tentu memberi jaminan bahwa kesenjangan pendapatan akan rendah pula.

Secara agregat bisa saja terjadi pertumbuhan ekonomi tetapi pertumbuhan dan peningkatan tersebut tidak dialami oleh seluruh masyarakat, tetapi hanya dikontribusi oleh sekolompok masyarakat tertentu. Todaro (1999) mengatakan bahwa pada dasarnya pembangunan ekonomi mempunyai empat dimensi pokok yaitu: (1) pertumbuhan ekonomi, (2) penanggulangan kemiskinan, (3) perubahan atau transformasi ekonomi dan (4) keberlanjutan pembangunan dari masyarakat agraris ke masyarakat industri. Oleh sebab itu, transformasi struktural merupakan prasyarat dari peningkatan dan kesinambungan pertumbuhan serta penanggulangan kemiskinan sekaligus pendukung bagi keberlanjutan pembangunan itu sendiri. 
Abdul Rasyid, Pengaruh Tenaga Kerja dan Daya Dorong Investasi ... 2

Tabel 4 Pertumbuhan Ekonomi Provinsi Papua Berdasarkan harga Berlaku dan Harga Konstan Tahun 2007-2014

\begin{tabular}{lrcrc}
\hline Tahun & $\begin{array}{c}\text { Atas Dasar Harga Berlaku } \\
\text { Nilai Nominal }\end{array}$ & $\begin{array}{c}\text { Atas Dasar Harga Konstan } \\
\text { \% Pertumbuhan }\end{array}$ & Nilai Nominal & \% Pertumbuhan \\
\hline 2007 & $55.365 .777,53$ & 18,07 & $19.176 .080,16$ & 4,28 \\
2008 & $54.733 .627,98$ & $-1,17$ & $18.914 .877,29$ & 8,79 \\
2009 & $56.561 .852,39$ & 22,92 & $22.926 .545,76$ & 20,34 \\
2010 & $110.808 .176,62$ & 89,45 & $110.808 .176,61$ & -48 \\
2011 & $108.188 .756,41$ & 6,99 & $106.066 .723,30$ & $-4,28$ \\
2012 & $112.812 .560,53$ & 7,16 & $107.890 .942,50$ & 1,72 \\
2013 & $122.857 .170,47$ & 11,79 & $117.118 .818,90$ & 8,55 \\
2014 & $133.329 .981,21$ & 9,94 & $121.391 .233,95$ & 3,81 \\
\hline
\end{tabular}

Sumber Data : BPS Provinsi Papua, Papua Dalam Angka

Berdasarkan tabel 4 dapat dijelaskan bahwa pertumbuhan ekonomi di Provinsi Papua tahun 2007 berdasarkan harga konstan adalah sebesar $.4,28$ persen, tahun 2008 sebesar 8,79 persen, tahun 2009 naik menjadi 20,34 persen, lalu tahun 2011 turun drastis ke $-4,28$ persen. Meskipun sempat mengalami kenaikan pada tahun 2013 dengan tingkat pertumbuhan mencapai 8,55 persen namun turun kembali menjadi 3,81 persen di tahun 2014. Dalam kaitannya dengan peningkatan laju pertumbuhan ekonomi khusunya di Provinsi Papua maka diperlukan kajian yang lebih mendalam agar pengaruh human capital dan daya dorong investasi menjadi penopang terhadap penyediaan kesempatan kerja dan pertumbuhan ekonomi Provinsi Papua.

\section{Pembahasan}

Laju pertumbuhan penduduk yang tinggi akan menimbulkan banyak masalah bagi setiap wilayah jika tidak diikuti dengan peningkatan produksi dan efisiensi di bidang lainnya. Banyaknya jumlah penduduk akan menambah beban sumber daya produktif terhadap sumber daya yang belum produktif yang akibat lanjutnya akan menciptakan masalah sosial yang cukup rumit. Oleh karena itu, jumlah penduduk dianggap sebagai sumber daya manusia yang potensial untuk memajukan perekonomian suatu wilayah, dimana tenaga kerja merupakan salah satu faktor produksi dalam meningkatkan produksi suatu perusahaan, dengan jumlah penduduk yang ada saat ini, maka Provinsi Papua memiliki potensi persediaan tenaga kerja yang cukup, tetapi tidak semua yang potensial tersebut dapat terserap di tiap sektor produksi sehingga menimbulkan pengangguran.

Pertumbuhan ekonomi merupakan prasyarat untuk mengakselerasikan pembangunan ekonomi keseluruhan. Intinya, kunci sukses pembangunan adalah terjadinya pertumbuhan ekonomi yang cukup tinggi, pemerataan distribusi pembangunan dan dinamisnya stabilitas sosial maka perlunya peningkatan dari sisi investasi yang akan menunjang pertumbuhan ekonomi. Oleh sebab itu, pertumbuhan tenaga kerja yang kurang diimbangi dengan pertumbuhan lapangan kerja akan menyebabkan tingkat kesempatan kerja cenderung menurun. Meski demikian, jumlah penduduk yang bekerja tidak selalu menggambarkan jumlah kesempatan kerja.

Investasi merupakan salah satu faktor yang penting dalam pertumbuhan perekonomian suatu negara. Provinsi Papua sebagai wilayah yang memiliki potensi yang besar, dalam hal ini tentunya juga berupaya menarik investor sebanyak-banyaknya. Provinsi Papua memiliki daya tarik di 
antaranya dikarenakan memiliki sumber daya manusia yang potensial meskipun masih sangat terbatas. Namun sayangnya, penyebaran sumberdaya manusia Provinsi Papua belum merata dan belum banyak terdidik. Hal inilah yang seharusnya menjadi perhatian khusus pemerintah daerah dalam upaya memajukan perekonomian daerah.

Menurut Sukirno (2000), kegiatan investasi yang dilakukan oleh masyarakat secara terus-menerus akan meningkatkan kegiatan ekonomi dan kesempatan kerja, meningkatkan pendapatan nasional dan meningkatkan taraf kemakmuran masyarakat. Peranan ini bersumber dari tiga fungsi penting dari kegiatan investasi, yakni (1) investasi merupakan salah satu komponen dari pengeluaran agregat, sehingga kenaikan investasi akan meningkatkan permintaan agregat, pendapatan nasional serta kesempatan kerja; (2) pertambahan barang modal sebagai akibat investasi akan menambah kapasitas produksi; (3) investasi selalu diikuti oleh perkembangan teknologi

Demikian pula oleh Hasibuan (1987), tentang pengertian investasi secara makro ekonomi diartikan bahwa modal dana yang diinvestasikan itu akan menambah produksi, menaikkan pendapatan nasional dan memperluas lapangan kerja. Karena itu pembangunan ekonomi pada umumnya didefinisikan sebagai suatu proses yang menyebabkan pendapatan per kapita penduduk suatu masyarakat meningkat dalam jangka panjang (Sukirno, 1985).

Pembangunan ekonomi mempunyai tiga sifat penting, yaitu pembangunan ekonomi merupakan: suatu proses, yang berarti merupakan perubahan yang terjadi secara terus menerus, maka untuk menaikan tingkat pendapatan per kapita itu harus terus berlangsung dalam jangka panjang. Sedangkan pertumbuhan ekonomi (economicgrowth) diartikan sebagai kenaikan dalam GDP, tanpa memandang apakah kenaikan itu lebih besar atau lebih kecil daripada tingkat pertambahan penduduk, atau apakah perubahan dalam struktur ekonomi berlaku atau tidak
(Sukirno, 1985).

Oleh karena pembangunan selalu menimbulkan dampak, baik positif maupun negatif maka diperlukan berbagai indikator sebagai tolok ukur terjadinya pembangunan (Kuncoro, 1997). Adapun indikatorindikator kunci pembangunan secara garis besar pada dasarnya dapat diklasifikasikan:

1. Indikator Ekonomi, yang terdiri dari :

a. GNP per kapita,

b. Laju pertumbuhan ekonomi, dan

c. GDP per kapita dengan Purchasing Power Parity

2. Indikator Sosial, yang terdiri dari

a. HDI (Human Development Index),

b. PQLI (Physical Quality Life Index) atau Indeks Mutu Hidup.

3. Konsep dan Teori Pertumbuhan dan Pembangunan Daerah

Masalah pertumbuhan ekonomi (economic growth) telah mendapat perhatian yang cukup besar, yaitu sejak munculnya ilmu ekonomi. Menurut Nanga (2005), pertumbuhan ekonomi dibutuhkan dan merupakan sumber utama peningkatan standar hidup (standard of living) penduduk yang jumlahnya terus meningkat. Dengan kata lain, kemampuan ekonorni suatu negara untuk meningkatkan standar hidup penduduknya adalah sangat bergantung dan ditentukan oleh laju partumbuhan ekonomi jangka panjangnya (long run rate of economic growth). Tapi menurut Senghaas (1988), yang menentukan bukanlah pertumbuhan itu sendiri melainkan ditentukan oleh dampak perluasan pertumbuhan dan sejauhmana dapat terbentuk perekonomian yang koheren dengan adanya dorongan pertumbuhan sektoral. Dari teori pertumbuhan ekonomi didefinisikan sebagai penjelasan mengenai faktor-faktor apa yang menentukan kenaikan output per kapita dalam jangka panjang, dan penjelasan mengenai bagaimana faktorfaktor tersebut berinteraksi satu sama lain, sehingga terjadi proses pertumbuhan (Boediono, 1992).

Untuk itu, secara singkat diungkapkan oleh Richardson (1977) dan lebih diperjelas lagi oleh Arsyad (1999) 
bahwa ada beberapa teori yang berhubungan dengan teori pertumbuhan dan pembangunan daerah, yaitu Teori Basis Economi (Economic Base Theory). Istilah kesempatan kerja mengandung pengertian lapangan pekerjaan atau kesempatan yang tersedia untuk bekerja akibat dari suatu kegiatan ekonomi. Dengan demikian pengertian kesempatan kerja adalah mencakup lapangan pekerjaan yang sudah terisi dan semua lapangan pekerjaan yang masih lowong. Dari lapangan pekerjaan yang masih lowong tersebut (yang mengandung arti masih ada kesempatan), kemudian timbul kebutuhan akan tenaga kerja (Anonim, 1990). Karena itu, pengertian angkatan kerja, bukan angkatan kerja, kesempatan kerja dan menganggur atau mencari pekerjaan (Anonim, 1990) masing masing adalah sebagai berikut :

1. Angkatan kerja terdiri dari penduduk yang berusia sepuluh tahun ke atas yang sudah bekerja, punya pekerjaan tetapi sementara tidak bekerja ataupun sedang mencari pekerjaan.

2. Bukan angkatan kerja mencakup penduduk yang beumur sepuluh tahun ke atas yang dalam satu minggu sebelum pencacahan tidak bekerja, tidak punya pekerjaan maupun mencari pekerjaan tetapi hanya melakukan kegiatan seperti: sekolah di sekolah formal, mengurus rumah tangga ataupun karena kondisi fisik yang sudah tidak memungkinkan untuk melakukan berbagai aktifitas, cacat mental ataupun karena lanjut usia.

3. Kesempatan kerja yang biasanya digunakan dalam setiap kesempatan kerja yang sudah termasuk lapangan pekerjaan yang sudah diduduki dan masih lowong.

4. Menganggur atau mencari pekerjaan atau unemployment adalah penduduk yang termasuk dalam angkatan kerja yang tidak bekerja atau sedang mencari pekerjaan.

5. Konsep dan teori Produk Domestik Regional Bruto.

Schultze (1981) yang dikuatkan oleh Badan Pusat Statistik (Anonimous, 1996) bahwa PDRB (Produk Domestik Regional
Bruto) adalah jumlah nilai tambah bruto (gross value added) yang timbul dari seluruh sektor perekonomian suatu wilayah. Nilai tambah adalah nilai produksi (output) dikurangi biaya antara. Sedangkan nilai tambah bruto mencakup komponenkomponen pendapatan dari faktor upah dan gaji, bunga, sewa tanah dan keuntungan, penyusutan dan pajak tidak langsung netto. Menghitung nilai tambah bruto dari masingmasing sektor dan menjumlahkan nilai tambah bruto dari seluruh sektor dimaksud akan diperoleh PDRB (Produk Domestik Regional Bruto). Sedangkan struktur ekonomi adalah gambaran perekonomian yang disajikan menurut sektor. Persentase hasil dari setiap sektor tersebut menjadi ukuran besar kecilnya sumbangan atau kontribusi dari masing masing sektor perekonomian.

Selain itu perlu juga diketahui tentang PDRB per kapita. Badan Pusat Statistik (Anonimous, 1996) bahwa PDRB per kapita adalah merupakan gambaran nilai tambah yang bisa diciptakan oleh masing masing penduduk suatu daerah akibat adanya aktivitas produksi. Data tersebut dapat diperoleh dengan cara membagi total nilai PDRB dengan jumlah penduduk pertengahan tahun (karena penyebarannya dianggap lebih merata).

Menurut Glasson (1990) bahwa konsep tentang wilayah merupakan sebagai konsep wilayah yang timbul melalui dua fase yang berbeda yaitu: yang mencerminkan kemajuan perekonomian dari sektor pertanian sederhana ke sistem industri yang kompleks sebagai fase yang memperlihatkan wilayah formal sedangkan fase kedua adalah menyangkut wilayah fungsional.

Beberapa Indikator Makro Ekonomi Provinsi Papua:

a. Laju Pertumbuhan dan Investasi di Provinsi Papua

Sebagaimana uraian di atas bahwa investasi terdiri dari penanaman modal asing dan penanaman modal dalam negeri. Perkembangan investasi penanaman modal asing dan penanaman modal dalam negeri meningkat dari tahun ke tahun. Laju 
pertumbuhan penanaman modal asing mengalami angka yang tertinggi terjadi pada tahun 2014 yakni sebesar 58,06 persen dengan jumlah investor sebanyak 108 investor. Sedangkan investasi penanaman modal negeri sebesar 41,94 persen dengan jumlah investor sebanyak 78 investor. Investasi dalam negeri ini bersumber dari investasi pemerintah dan swasta, di mana pemerintah mempunyai andil yang cukup besar terhadap perkembangan investasi di Provinsi Papua sebagai dampak dari Otonomi khusus.

b. Pertumbuhan Kesempatan Kerja di Provinsi Papua

Seiring dengan pertumbuhan penduduk maka pertumbuhan tenaga kerja juga terus meningkat. Untuk itu, pemerintah selalu berupaya agar jumlah penduduk yang masuk pasar kerja harus seimbang dengan kesempatan kerja yang ada. Data yang ada tentang perkembangan kesempatan kerja dari tahun 2007- 2014 menunjukkan kecenderungan peningkatan yang cukup signifikan.

Rata-rata pertumbuhan kesempatan kerja di Provinsi Papua dari tahun 20072014 adalah sebesar 0,68\%. Pertumbuhan kesempatan kerja di Provinsi Papua menurut lapangan usaha adalah sektor pertambangan dan galian. Selain itu ada sektor sektor pertanian yang juga merupakan sektor yang penyedia kesempatan kerja. Selain bangunan, sektor-sektor jasa-jasa juga pemberi sumbangan kesempatan kerja di Provinsi Papua, dan terkecil adalah sektorsektor lain seperti listrik, air dan restoranrestoran.

c. Pertumbuhan Pendapatan per kapita Masyarakat (PDRB per kapita) Provinsi Papua.

Pendapatan per kapita masyarakat merupakan gambaran rata-rata pendapatan yang diterima oleh setiap penduduk sebagai hasil dari proses produksi. Pendapatan per kapita suatu daerah adalah pendapatan regional daerah (PDRB) tersebut dibagi dengan jumlah penduduk pertengahan tahunnya. Tingkat dan laju pertumbuhan PDRB per kapita dipakai sebagai salah satu indikator untuk mengukur tingkat ekonomi rakyat.

PDRB per kapita atas dasar harga berlaku menunjukkan pendapatan yang dinikmati per orang penduduk, dan PDRB per kapita atas dasar harga konstan berguna untuk menggambarkan pertumbuhan nyata atau riel ekonomi per kapita. Menurut Sukirno (2011) pertumbuhan ekonomi merupakan perkembangan kegiatan dalam perekonomian yang menyebabkan barang dan jasa yang diproduksikan dalam masyarakat bertambah. Pertumbuhan ekonomi merupakan kenaikan PDB atau PNB rill.

Perkembangan PDRB per kapita Provinsi Papua berdasarkan harga berlaku dari tahun 2007- 2014 menunjukkan angka yang tidak signifikan, walaupun pada tahun yang sama 2008 terjadi krisis ekonomi melanda Indonesia dimana Provinsi Papua memiliki tingkat pertumbuhan ekonomi mencapai 8,79 persen, namun tidaklah merata dirasakan oleh setiap daerah dan tidak dikonstribusi oleh seluruh penduduk tetapi dikontribusi oleh sekelompok masyarakat. Rata rata pertumbuhan PDRB per kapita Provinsi Papua berdasarkan harga berlaku dan harga konstan dari tahun 2007 hingga 2014 adalah masing-masing sebesar 19,39 persen dan -0,24 persen.

Perturnbuhan pendapatan per kapita berdasarkan harga berlaku tahun mengalami angka pertumbuhan tertinggi terjadi pada tahun 2010 yakni sebesar 89,45 persen, sedangkan laju pertumbuhan ekonomi berdasarkan harga kontan terjadi pada tahun 2009 dengan tingkat pertumbuhan sebesar 20,34 persen. Dengan demikian, rata-rata pertumbuhan PDRB per kapita Provinsi Papua berdasarkan harga berlaku dan harga konstan dari tahun 2007 sampai dengan tahun 2014 masing-masing adalah sebesar 19,39 persen dan -0,24 persen.

d. Elastisitas Kesempatan Kerja

Pertumbuhan kesempatan kerja dari tahun ke tahun cenderung mengalami peningkatan. Perbandingan antara persentase pertumbuhan kesempatan kerja dengan persentase pertumbuhan Produk 
Domestik Regional Bruto (PDRB) akan menghasilkan elastisitas kesempatan kerja. Jika angka elastisitas kesempatan kerja lebih besar 1 disebut elastis, jika elastisitas kesempatan kerja sama dengan 1 disebut elastis uniter, dan jika elastisitas kesempatan kerja lebih kecil 1 disebut tidak elastis. Elastisitas kesempatan kerja yang tertinggi disebut elastis karena persentase pertumbuhan kesempatan kerja lebih besar dari persentase pertumbuhan produk domestik regional bruto (PDRB).

Elastisitas kesempatan kerja mengalami angka yang terkecil pada tahun 2007 dan persentase produk domestik regional bruto (PDRB) juga sangat kecil. Laju pertumbuhan produk domestik regional bruto (PDRB) pada tahun yang sama, dengan persentase rata-rata angka pertumbuhan PDRB adalah $-0,24$ persen, kondisi itu terjadi akibat dari kenaikan harga-harga kebutuhan pokok dan masalahmasalah sosial lainnya, sehingga berdampak rendahnya tingkat pertumbuhan ekonomi.

Penyediaan kesempatan kerja di propinsi Papua dipengaruhi oleh penanaman modal asing dan penanaman modal dalam negeri. Investasi penanaman modal asing dan penanaman modal dalam negeri nyata berpengaruh terhadap penyediaan kesempatan kerja meskipun tidak signifikan. Hal ini disebabkan karena penanaman modal asing dan penanaman modal dalam negeri, banyak didukung oleh pemerintah melalui anggaran pembiayaan pembangunan yang penggunaanya lebih berorientasi pada pembangunan sektor-sektor yang kurang menyerap tenaga kerja, misalnya belanja untuk fasilitas umum (sarana dan prasarana), belanja pendidikan dan pengajaran, dan lain -lain.

Investasi penanaman modal asing dan penanaman modal dalam negeri sama-sama berpengaruh nyata terhadap pendapatan per kapita dan pertumbuhan ekonomi meskipun tidak signifikan. Untuk dapat merealisasi semua sumber pendapatan daerah maka diperlukan kebijakan pembangunan daerah yang tepat sesuai dengan permasalahan yang dihadapi dan harus ada keberpihakan pemerintah daerah terhadap sektor-sektor produktif yang mendukung investasi dan pencipta lapangan kerja, sehingga pendapatan per kapita masyarakat bisa meningkat dan laju pertumbuhan ekonomi juga terus tumbuh. Terdapat beberapa langkah yang dapat dilakukan oleh pemerintah daerah sebagai ujung tombak pengambil kebijakan adalah sebagai berikut :

a. Pemerintah perlu memperhatikan bahwa sebuah kebijakan adalah sebagai fenomena positif untuk meningkatkan investasi penanaman modal asing (PMA) dan penanaman modal dalam negeri (PMDN) dengan melakukan reformasi birokrasi layanan investasi, membangun sistem informasi potensi investasi, serta peningkatan infrastruktur fisik, baik jalan maupun jembatan sebagai penghubung antar daerah.

b. Bahwa kebijakan arah alokasi pengeluaran pembangunan terhadap sektorsektor produktif belum mampu berbuat banyak untuk menggerakkan sektor-sektor lainnya. Untuk itu, diperlukan kebijakan dari pemerintah daerah yang lebih konsisten dalam mengidentifikasi sektor-sektor produktif untuk menggerakkan sector-sektor lainnya. Selain memperhatikan sektor produktif, pemerintah daerah Propinsi Papua harus memberikan perhatian sepenuhnya pada kebijakan pembangunan yang mempersempit ketimpangan antar daerah.

c. Harus ada keberpihakan bahwa pemerintah daerah harus mampu memberikan jaminan keamanan dan ketenangan bagi semua investor dengan melakukan penyempurnaan regulasi yang terkait dengan jaminan kesejahteraan setiap investor yang melakukan aktivitas di daerah. Termasuk kemudahan di dalam mengurus perizinan usaha sehingga mampu merangsang investor asing maupun lokal untuk berinvestasi.

d. Pemerintah daerah harus mampu memacu akselerasi pertumbuhan ekonomi daerah. Oleh karena itu, Pemerintah Daerah perlu mengembangkan fungsi dari Kawasan 
Pembangunan Ekonomi Terpadu (Kapet) dan fungsi Kamar Dagang dan Industri (KADIN), sehingga akan memberikan dampak positif terhadap pembangunan ekonomi daerah.

e. Pemerintah daerah harus mampu menyiapkan data informasi terhadap potensi yang dimiliki oleh daerah, sehingga investor bisa lebih mudah memilih jenis investasi yang layak dan murah namun tetap bisa memberikan kontribusi terhadap penyediaan lapangan kerja dan peningkatan pendapatan masyarakat dan mendukung terus tumbuhnya ekonomi daerah.

\section{KESIMPULAN}

(1) Sejak tahun 2007 hingga 2014, pertumbuhan investasi penanaman modal asing (PMA) dan penanaman modal dalam negeri (PMDN) di Provinsi Papua terus tumbuh dan berkembang; (2) Pertumbuhan kesempatan kerja di Provinsi Papua tahun 2007 sampai 2014 terus mengalami pertumbuhan meskipun tidak terlalu besar; (3) Tingkat pertumbuhan pendapatan per kapita di Provinsi Papua dari tahun 2007 sampai 2014 berdasarkan harga berlaku dan konstan relatif tidak stabil, meskipun sektor pertambangan dan lain-lain dan cukup besar dalam menyediakan kesempatan kerja dan peningkatan pendapatan per kapita; (4) Investasi penanaman modal asing (PMA) dan penanaman modal dalam negeri (PMDN) di Provinsi Papua belum berpengaruh signifikan terhadap kesempatan kerja dan pendapatan per kapita, karena investasi penanaman modal asing (PMA) dan penanaman modal dalam negeri (PMDN) di Provinsi Papua masih lebih terorientasi pada pembangunan sektor-sektor yang kurang menyerap tenaga kerja.

Oleh karena itu, kebijakan pembangunan daerah untuk meningkatkan investasi di Provinsi Papua perlu dilakukan seperti: (1) Melakukan reformasi birokrasi layanan investasi, membangun sistem informasi potensi investasi, serta peningkatan provisi infrastruktur fisik; (2) Kebijakan arah alokasi pengeluaran pembangunan terhadap sektorsektor produktif belum mampu berbuat banyak untuk menggerakkan sektor-sektor lainnya. Untuk itu diperlukan kebijakan dari pemerintah daerah yang lebih konsisten dalam mengidentifikasi sektor-sektor produktif untuk menggerakkan sektor-sektor lainnya; (3) Kebijakan pemerintah daerah untuk mengembangkan fungsi Kawasan Pembangunan Ekonomi Terpadu (Kapet) dan fungsi Kamar Dagang dan Industri (Kadin), sesuai dengan fungsinya masingmasing; (4) Kebijakan pemerintah sebagai parner investor dalam pemberi layanan yang terkait dengan data dan informasi; (5) Pemerintah daerah perlu menciptakan iklim yang favorable untuk semakin berkembangnya investasi penanaman modal asing (PMA) dan penanaman modal dalam negeri (PMDN) di Provinsi Papua; (6) Untuk pemenuhan permintaan pasar kerja, maka perlunya dilakukan pengembangan sumber daya rnanusia dengan membuka berbagai lembaga pendidikan formal dan non formal, sehingga peluang sumber daya manusia lebih terbuka; (7) Untuk menarik investor agar dapat menanamkan modalnya di Provinsi Papua, maka faktor penghambat pengembangan investasi yang utama berupa kepastian hukum, masalah tanah adat masyarakat adat dan masalah infra struktur harus mendapat perhatian penuh dari masyarakat dan pemerintah daerah serta pemberian insentif kepada dunia usaha berupa keringanan pajak retribusi daerah, kemudahan mendapatkan perizinan dan kepastian pengawasan perizinan penanaman modal sehingga pengusaha (investor) merasa diperhatikan; (8) Diperlukan peningkatan alokasi anggaran dari pemerintah untuk menunjang berbagai kegiatan investasi terutama peningkatan infrastruktur fisik untuk mendorong pertumbuhan ekonomi. Dan perlu adanya perhatian pemerintah daerah sehubungan dengan Peraturan Daerah (Perda) yang mengatur pelaksanaan dan kewenangan penanaman modal antara Provinsi dan Kabupaten Kota. 


\section{DAFTAR PUSTAKA}

Anonimous. 1990. PPKN. Jakarta: Departamen Tenaga Kerja.

Anonimous. 1996. Perhitungan PDRB Kabupaten Kotamadya Dasar dan Teori. Jakarta: Badan Pusat Statistik.

Arsyad, L. 1997. Ekonomi Pembangunan. Edisi Ill. Yogyakarta: Sekolah Tiggi llmu Ekonomi YKPN.

Arsyad, L. 1999. Pengantar Perencanaan dan Pembangunan Ekonomi Daerah. Yogyakarta: BPFE.

Boediono. 1992. Teori Pertumbuhan Ekonomi. Yogyakarta: BPFE.

Christy, Fhino Andrea dan Adi, Priyo Hari. 2009. Hubungan Antara DAU, Belanja Modal dan Kualitas Pembangunan Manusia, The 3rd National Conference UKWMS di Surabaya Oktober 2009.

Djoyohadikusumo, S. 1994. Perkembangan Pemikiran Ekonomi: Dasar Teori Ekonomi Pertumbuhan dan Ekonomi Pembangunan. Jakarta: LP3ES.

Glasson, J. 1990. PengantarPerencanaanRegional Terjemahan Sitohang, P. Jakarta: Lembaga Penerbit FEUI.

Gray, C., dan Simanjuntak, P., Lien, K., Maispatella, Varley. 1993. Pengantar Evaluasi Proyek Jakarta: Gramedia.

Hasibuan, M.S.P. 1987. Ekonomi Pembangunan dan Perekonomian Indonesia. Bandung: Penerbithico.

Kunarjo. 1993. Perencanaan dan Pembiayaan Pembangunan. Jakarta: UIPress.

Nanga, M. 2005. Makro Ekonomi, Teori, Masalah dan Kebijakan. Edisi kedua. Jakarta: Penerbit PT Raja Grafido Persada.

Richardson, H.W. 1997.Dasar-dasar Ilmu Ekonomi Regional (terjemahan). Jakarta: LP - FEUI.

Sukirno, S., 2000. Makroekonomi Modern. Jakarta: Raja Grafindo Pustaka

Schultze, Ch.L. 1981. Analisis Pendapafan Nasional, Stabilitas dan Pertumbuhan. Diterjemahkan oleh St. Dianjung. Jakarta: PT Bina Aksara.
Senghaas, D. 1988. Tala Ekonomi Dunia dan Politik Pembangunan (terjemahan) oleh Aan Efendi. Jakarta: LP3ES.

Simanjuntak, J.P. 1998. Pengantar EkonomiSumber Daya Manusia. Jakarta: Fakultas Ekonomi Universitas Indonesia.

Sukirno, S. 1985a. Beberapa Aspek dalam Persoalan Pembangunan Daerah. Jakarta: LPFE-UI.

Sukirno, Sadono. 2011. Makroekonomi Teori Pengantar. Rajawali Pers. Jakarta

Sukirno, S. 1985b. EkonomiPembangunan. Jakarta: LPFE- UI.

Waqmni, S. 1984. Analisa Kota dan daerah. Bandung: ITB Bandung.

Winardi. 1979. Pengantar Ilmu Ekonomi, (Teori Perfurnbuhan Ekonomi). Edisi V. Bandung: Tarsito.

Wiardi. 1992. Kamus Ekonomi. Bandung:

Alumni. 